JOSING: Journal of Nursing and Health

Volume 1, Nomor 2, Juni 2021

e-ISSN: 2745-7877

p-ISSN: 2746-0851

DOI: https://doi.org/10.31539/josing.v1i2.2325

\title{
MOTHERS AWARENESS OF PNEUMONIA AND THE TODDLER BREASTFEEDING DURATION AFFECT PNEUMONIA INCIDENCE
}

\author{
Def Primal $^{1}$, Yendrizal Jafri $^{2}$, Andrye Fernandes ${ }^{3}$ \\ Indonesian Perintis University ${ }^{1,2,3}$ \\ def.primal.anatomy@gmail.com ${ }^{1}$
}

\begin{abstract}
This study aims to determine the relationship between the mother's level of awareness about the pathology of pneumonia and the duration of breastfeeding under five with the incidence of pneumonia in DR. M.A. Hospital Hanafiah. This research is a retrospective analytic descriptive study with a cross-sectional design. The results showed that mothers' awareness of pneumonia was lower by $71.8 \%$, they breastfed their babies for less than six months (71.8\%), and more than two-thirds of children under five (76.9\%) were diagnosed with pneumonia. Furthermore, statistical analysis significantly correlated the mothers' awareness of pneumonia and the duration of breastfeeding they performed on their children with pneumonia. The conclusion is that the mother's understanding of pneumonia has a linear effect on the incidence of pneumonia in infants and toddlers. The duration of breastfeeding has a significant impact. We assume that non-exclusive breastfeeding in infants stimulates underweight and immunological disorders that accelerate the incidence of pneumonia.
\end{abstract}

Keywords: Mother's Awareness, Length of Breastfeeding, Toddler Pneumonia

\section{INTRODUCTION}

Pneumonia is an acute infectious disease that directly strikes the lung tissue (alveoli), which has an etiological induction from various microorganisms' invasion, such; viruses, fungi, and bacteria (Padila et al., 2020). Symptoms commonly include chills sensation, fever, continuous headache, cough, hypersecretion of laryngopharyngeal sputum, and shortness of breath. The one suggested effort controlling this disease is to increase the detection of pneumonia in toddlers (Ministry of Health RI, 2016). The World Health Organization (WHO) 2015 reported that nearly 6 million children under five died. As the number 1 killer of children under five globally, it contributes $16 \%$ of death by pneumonia. (Mendri \& Prayogi, 2017).

The World Health Organization (WHO) report in the 2016 world health report stated that the five primary lung diseases accounted for $17.4 \%$ of all deaths in the world, each consisting of 7.2\% lung infection, COPD (Chronic Obstructive Pulmonary Disease) $4.8 \%$, tuberculosis $3.0 \%$, lung/trachea/bronchial cancer $2.1 \%$ and asthma $0.3 \%$ (Harsismanto et al., 2020; Infodatin, 2017).

In Indonesia in 2014, the coverage rate of pneumonia found in children under five has not developed significantly, approximately $20-30 \%$. A year after, it increased, becoming $63.45 \%$. In 2016, there was a slight decreasing coverage of pneumonia findings for children under five by $57.84 \%$. However, in the West Sumatra province, public health data stated that pneumonia incidence in a toddler was $74.27 \%$ (Ministry of Health, RI, 2017). Furthermore, the absolute data from Tanah Datar region coverage revealed that the 
pneumonia case was $22 \%$ higher than any surrounding region in this province, not more than $13.0 \%$. (West Sumatra Health Office, 2014). Patients with pneumonia in toddler age recorded from the general hospital in Tanah Datar reached out for 354 to 523 patients in 2015 and 2016, respectively. Meanwhile, the data obtained by pneumonia patients who visited the children's polyclinic in 2016 were 169 people, and in 2017 from January to August, 88 people were accepted.

Related to Erin et al., (2015) research finding, concerned the relationship between the level of education with pneumonia prevention behavior in children under five that revealed $37 \%$ respondents out of 59. They showed several risk factors contributing to pneumonia, including malnutrition, low exclusive breastfeeding, indoor air pollution, common measles immunization coverage, and low birth weight (Ministry of Health RI, 2016).

From various risk factors contributing to the incidence of pneumonia, non-exclusive breastfeeding is a primary risk factor that needs more attention without ignoring other risk factors. Because of exclusive breastfeeding, many benefits contribute to both mother's and her children's health development. It is a natural way of feeding activity for infants. Based on those phenomena, we eager to determine the correlation of mother's awareness level to pneumonia and the breastfeeding duration they performed towards their pneumoniadiagnosed toddler.

\section{RESEARCH METHOD}

This research is a descriptive retrospective analytic study with a cross-sectional design to indicate mother's level of knowledge or awareness towards pneumonia and the breastfeeding duration they performed to the incidence of toddlers pneumonia in the DR. M.A. Hanafiah Hospital pediatric polyclinic. We accumulated the research data from validated research questioners and supported by the patient's medical records, as our secondary data. This research was conducted at the hospital's pediatric polyclinic for over 4 weeks period, in February 2018. We collected and validated the questioners answered related to mother's knowledge or awareness on pneumonia and the length of breastfeeding they performed to their toddler-age children. We compared and added additional information on their medical record also.

Data processing and analysis were carried out from computerized calculations. Univariate analyses were performed descriptive value and overview of the mother's knowledge or awareness level on pneumonia, the long period of breastfeeding, and the incidence of toddler pneumonia as a research dependent variable. On the other hand, bivariate analysis has identified the determination of variables correlations.

\section{RESULTS}

Table. 1

Mother's Awareness on Pneumonia, Breastfeeding Duration Performed, and Toddlers Pneumonia Incidence

\begin{tabular}{llll}
\hline \multicolumn{1}{c}{ Research variables } & $\mathrm{f}$ & $\%$ & $\mathrm{n}$ \\
\hline Awareness Level & & & \\
High & 11 & 28.2 & 39 \\
Low & 28 & 71.8 & \\
\hline Breastfeeding Duration & & & \\
Less than 6 Months (Non-Exclusive) & 28 & 71.8 & 39 \\
6 Months and More (Exclusive) & 11 & 28.2 & \\
\end{tabular}




\begin{tabular}{lccc}
\hline Toddlers Pneumonia Incidence & 30 & 76.9 & 39 \\
Diagnosed & 9 & 23.1 & \\
Healthy & & \\
\hline
\end{tabular}

The statistical result indicates more than half of the respondents with a low level of awareness about pneumonia for $71.8 \%$.

Table. 2

Mother's Awareness on Pneumonia and Breastfeeding Duration Performed Correlate to Toddlers Pneumonia Incidence

\begin{tabular}{|c|c|c|c|c|c|c|c|}
\hline \multirow{3}{*}{ Research Variables } & \multicolumn{4}{|c|}{ Pneumonia Incidence } & \multirow{3}{*}{$\mathrm{N}$} & \multirow{3}{*}{ OR } & \multirow{3}{*}{ P-Value } \\
\hline & \multicolumn{2}{|c|}{ Diagnosed } & \multicolumn{2}{|c|}{ Healthy } & & & \\
\hline & $\mathrm{f}$ & $\%$ & $\mathrm{f}$ & $\%$ & & & \\
\hline \multicolumn{8}{|l|}{ Awareness Level } \\
\hline High & 11 & 32.1 & 0 & 0 & 11 & 0.679 & 0.033 \\
\hline Low & 19 & 67.9 & 9 & 100 & 28 & & \\
\hline \multicolumn{8}{|l|}{ Breastfeeding } \\
\hline \multicolumn{8}{|l|}{ Duration } \\
\hline $\begin{array}{l}\text { Less than } 6 \text { Months } \\
\text { (non-Exclusive) }\end{array}$ & 19 & 67.9 & 9 & 100 & 28 & 0.679 & 0.033 \\
\hline $\begin{array}{l}6 \text { Months and More } \\
\text { (Exclusive) }\end{array}$ & 11 & 32.1 & 0 & 0 & 11 & & \\
\hline
\end{tabular}

Relating to table 2 we can figure out that our finding showed a significant correlation $(\mathrm{p}=0.033)$ on mother's awareness level to pneumonia towards the incidence of pneumonia in their toddler age children. We can find that 67.9 pneumonia diagnosed to the children correlate to the mothers less awareness of pneumonia sign and symptoms. However, high awareness of mothers to pneumonia still have a chance for over $30 \%$ experienced with pneumonia toddler.

\section{DISCUSSION}

The statistical result indicates more than half of the respondents with low awareness of pneumonia, for $71.8 \%$. This finding is similar to Azizah et al., (2014) results regarding the level of knowledge or understanding and mothers of under-five education to the incidence of pneumonia in their toddlers' children of Javanese people, for $78.7 \%$ in low level appealed.

What we assumed relating to mother's level of knowledge or awareness of pneumonia, more concerned they were to pneumonia, it has lower morbidity and mortality rate on toddler age. Meanwhile, mothers with a high understanding of pneumonia are rationally considered to be paying attention to pneumonia signs and symptoms.

Table 1 presented data are indicating that $28.2 \%$ of respondents breastfed their child exclusively ( 6 months and more). It was an insufficient number that should be considered having the opposite number what the health ministry goals. Physical environment and home conditions are mentioned as risk factors for pneumonia in toddlers. However, this proportion is exclusive breastfeeding in the last 24 hours and not fully until the child reached six months.

Exclusive breastfeeding is categorized as food without any additional ingredients for infants aged 0-6 months (Maryunani, 2012). children who are given breast milk are specially protected from diseases of the respiratory and digestive systems. We can figure that mothers have a higher awareness of the benefits and importance of exclusive 
breastfeeding, which directly can avoid various disease attacks relating to immune system invaders and infections.

Another research result indicates that children with suspect of pneumonia reached 76.9\%. We found similar research finding with Kaunang et al., (2016) description that pneumonia characteristics can be found in $<1$-year-old children for $68.4 \%$. Before the age of 3, toddlers stated for $24.7 \%$ incidence of pneumonia. Furthermore, preschool age(3-6 years) only experienced $4.4 \%$. Pneumonia is a general term for a lung infection caused by various germs (viruses, bacteria, fungi, and parasites). It is also defined as acute inflammation that attacks the lung tissue and its surroundings (Mendri \& Prayogi, 2017). Finally, we can explain that pneumonia incidence has the highest tendency to infect toddlerage children.

Relating to table 2, we can figure out that our finding showed a significant correlation $(\mathrm{p}=0.033)$ on mother's awareness level of pneumonia towards the incidence of pneumonia in their toddler-age children. We can find that 67.9 pneumonia diagnosed to the children correlate to the mother's less awareness of pneumonia signs and symptoms. However, a high understanding of mothers to pneumonia still has a chance for over $30 \%$ experienced with pneumonia. We believe that those conditions have stimulating factors such as room humidity, cleanliness of the house from endogenous and exogenous pathogens, and environments surrounding them. Our findings have inline research result by Azizah et al., (2014) that respondents involved from the Javanese region expressed an association between the level of knowledge and education of under-five mothers to the incidence of pneumonia.

Clients who have a low level of knowledge or awareness tend to have many questions about illnesses suffered by their family or children due to ignorance and then obey every suggested indication, implication, or therapy to improve their health condition (Harsismanto et al., 2020 ). The process is based on knowledge of awareness and a positive attitude so that the behavior will last. Conversely, if the behavior is not based on knowledge and understanding, it will not last long.

Based on the researcher's assumption, the higher of knowledge/ awareness and experience built up by the mother, they tend to immediately alert their toddler's prevention efforts, which can then suppress the morbidity and mortality rate related to pneumonia incidence. Our study showed a significant correlation $(p<0.05)$ between the length of breastfeeding and the incidence of pneumonia in the pediatric polyclinic. Even 11 respondents breastfed for over six months; it was still diagnosed as pneumonia. We believe it was caused by other factors such as the condition and cleanliness of the house or environment surroundings.

The study results were found to be associated with exclusive breastfeeding; under five with pneumonia did not differ from those without pneumonia in the case of fully exclusive breastfeeding for six months. However, the toddler with pneumonia had a complete breastfeeding duration of fewer than two months, as much as 5.24 times (95\%) than children without pneumonia. Some research results show that toddlers with pneumonia are more likely to be breastfed for less than five months than toddlers without pneumonia. These findings are consistent with the results of this study; toddlers with pneumonia received exclusive breastfeeding with a duration of fewer than two months. So there is a significant relationship between the length of breastfeeding and the incidence of pneumonia. 
Exclusive breastfeeding is prandial feeding through the developed lactiferous tissue in the mother's breast organ that purely without any additional external food for infants aged 06 months (Maryunani, 2012). Babies who are given breast milk are specially protected from diseases of the respiratory and digestive systems. What we assumed, the duration of breastfeeding against pneumonia, that is, more and more mothers are aware of the benefits and importance of exclusive breastfeeding for their toddlers, so it is a way to prevent pneumonia in toddler children and reducing the mortality rate for children under five due to pneumonia.

\section{CONCLUSION}

There is a significant correlation between the level of maternal awareness about pneumonia and the length of breastfeeding on toddler children to the incidence of pneumonia. It finally inference that mother's awareness level on pneumonia linearly affect pneumonia incidence in infants and toddlers, and consequently breastfeeding duration factor having a significant effect. We believe that non-exclusive breastfeeding in toddlers stimulates underweight and immunological disorders which accelerate pneumonia incidence.

\section{SUGGESTIONS}

We suggest that every health care provider should be paying intensive attention to problems we revealed, especially in maternal pneumonia education, and exclusive breastfeeding implementation.

\section{REFERENCES}

Azizah, M., Fahrurazi, F., \& Qoriaty, N. I. (2014). Tingkat Pengetahuan dan Pendidikan Ibu Balita dengan Kejadian Penyakit Pneumonia pada Balita di Kelurahan Keraton Kecamatan Martapura Kabupaten Banjar. Jurnal Kesehatan Masyarakat, Vol. 1, No. 1. https://ojs.uniska-bjm.ac.id/index.php/ANN/article/view/100

Dinkes Sumatera Barat. (2014). Profil Kesehatan 2014. Padang: Dinkes Sumatera Barat

Harsismanto, J., Padila, P., Andri, J., Andrianto, M, B., \& Yanti, L. (2020). Frekuensi Pernafasan Anak Penderita Asma Menggunakan Intervensi Tiup Super Bubbles dan Meniup Baling Baling Bambu. Journal of Telenursing (JOTING), 2(2), 119-126. https://doi.org/https://doi.org/10.31539/joting.v2i2.1409

Infodatin. (2017). Pusat Data dan Informasi Kesehatan RI. Jakarta

Kaunang, C. T., Runtunuwu, A, L., \& Wahani, A. M.I. (2016). Gambaran Karakteristik Pneumonia pada Anak yang Dirawat di Ruang Perawatan Intensif Anak RSUP Prof. Dr. R. D. Kandou Manado Periode 2013-2015. e-Clinic, 4(2), 1-9. https://doi.org/10.35790/ecl.v4i2.14399

Kemenkes RI. (2016). Profil Kesehatan Indonesia 2015. Jakarta: Kemenkes RI.

Kemenkes RI. (2017). Data dan Informasi Profil Kesehatan Indonesia 2016. Jakarta: Kemenkes RI

Maryunani, A. (2012). Inisiasi Menyusui Dini, ASI Ekslusif dan Manajemen Laktasi. Jakarta: TIM

Mendri, N. K., \& Prayogi, A. S. (2017). Asuhan Keperawatan pada Anak Sakit \& Bayi Resiko Tinggi. Yogyakarta: Pustaka Baru Press 
Nofitasari, E., Maryoto, M., Arni, R. N., \&Purnanto, T. N. (2015). Hubungan Tingkat Pengetahuan dan Tingkat Pendidikan dengan Perilaku Pencegahan Pneumonia pada Balita. Jurnal Keperawatan dan Kesehatan Masyarakat, 1(4), 1-10. https://doi.org/10.31596/jcu.v1i4.74

Padila, P., Harsismanto, J., Yanti, L., Setiawati, S., \& Andri, J. (2020). Meniup Super Bubbles dan Baling-Baling Bamboo pada Anak Penderita Pneumonia. Jurnal Keperawatan Silampari, 4(1), 112-119. https://doi.org/https://doi.org/10.31539/jks.v4i1.1545 